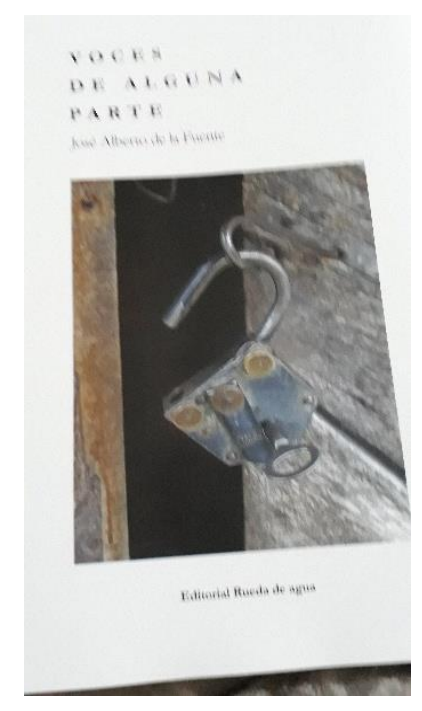

RESENHA: DE LA FUENTE, José. Voces de alguna parte. Santiago de Chile: Rueda de Agua, 2019, 84 p. [ISBN 978-956-8133-01-6]

\title{
Voces de alguna parte
}

\section{Sirio López Velasco ${ }^{1}$}

En este libro el Filósofo, Poeta y profesor universitario chileno nos ofrece un total de treinta y tres poemas donde se alternan o conjugan la sensibilidad ética y erótica con el compromiso humanista, ecológico y político. En los poemas "En el país de Jauja", "Chile, en cualquier día de 2017", y "Poética de la dignidad" el autor expresa con mucha pasión su nostalgia del Chile de Allende, su denuncia del Chile actual, y, sobre todo en el último, su apuesta a la esperanza en un país más humano y más respetuoso del medio ambiente; además de la esperanza en este último poema hace un verdadero y necesario llamado a perseverar en la búsqueda activa de ese nuevo país; en el primero de esos tres poemas son particularmente bellísimas las tres últimas estrofas. Para mejor situar al lector en relación a esos tres poemas hay que invitarlo a leer "Discurso de sobremesa", en el que De la Fuente hace una magistral síntesis de la historia de Chile; En "El occiso de la calle San Isidro" retrata la perplejidad que muchos compartimos ante un indigente tirado en la calle; y a ella se asocia la penúltima estrofa de "Al mundo se viene a vivir", donde se nos dice que, a pesar de esas desgarradoras vivencias, no estamos solos. En "El mejor poeta de Chile" el autor se burla a su manera de los grupejos que hacen esas clasificaciones, invitándonos con ironía a elegir al peor poeta chileno. Rima con ese desparpajo lo

\footnotetext{
${ }^{1}$ Filósofo e Professor Titular da FURG e Doutor em Filosofia pela Université Catholique de Louvain (1985). E-mail: lopesirio@hotmail.com
} 
que dice en "Oda a tu presencia", cuando homenajeando a su esposa exclama que la siente "desamparada y rebelde igual a mis poemas que nadie escucha". Dicho eso, de todas maneras, cumpliendo a cabalidad su misión de Filósofo, Literato y Docente, nuestro autor sigue lanzando ideas y poemas, esperando que algún día aparezca algún oído receptivo a sus interpelaciones éticas y líricas.

Submissão: 25. 09. 2019 / Aceite: 26. 09. 2019 